\title{
PENGARUH STRATEGI PEMBELAJARAN ELABORASI TERHADAP HASIL BELAJAR MATEMATIKA DITINJAU DARI MOTIVASI BELAJAR
}

\author{
ULFAH HERNAENY \\ ulfah_hernaeny@yahoo.co.id \\ EDWARD ALFIN \\ Program Studi Pendidikan Matematika, \\ FTMIPA, Universitas Indraprasta PGRI Jakarta. \\ Jln. Nangka No. 58c, Tanjung Barat, Jagakarsa, Jakarta Selatan
}

\begin{abstract}
Abstrak. Penelitian ini bertujuan untuk menganalisa tentang perbedaan pengaruh strategi pembelajaran matematika elaborasi dan konvensional terhadap hasil belajar matematika, pengaruh interaksi antara strategi pembelajaran matematika (elaborasi/konvensional) dan motivasi belajar matematika peserta didik, perbedaan hasil belajar matematika peserta didik yang belajar menggunakan strategi pembelajaran matematika elaborasi dan konvensional pada peserta didik yang bermotivasi belajar tinggi, perbedaan hasil belajar matematika peserta didik yang belajar menggunakan strategi pembelajaran matematika elaborasi dan konvensional, pada peserta didik yang bermotivasi rendah. Metode penelitian yang digunakan adalah metode eksperimen. Sampel sebanyak 60 peserta didik yang diambil secara random dan berstrata berdasarkan perbandingan jumlah peserta didik di setiap kelas. Analisis data meliputi: analisis deskriptif, uji normalitas, uji Homogenitas, uji Anova dua arah dan Uji Lanjut. Hasil penelitian menunjukan: 1) Hasil belajar matematika peserta didik yang belajar dengan strategi belajar elaborasi lebih tinggi dari peserta didik yang diajar dengan strategi konvensional, atau dengan kata lain terdapat perbedaan pengaruh yang signifikan antara strategi belajar elaborasi dengan konvensional terhadap hasil belajar matematika peserta didik. 2) Terdapat pengaruh interaksi yang signifikan antara strategi pembelajaran matematika dan tingkat motivasi belajar terhadap hasil belajar matematika peserta didik. 3) Pada kelompok peserta didik bermotivasi belajar tinggi, tidak terdapat perbedaan hasil belajar matematika yang signifikan antara yang diajar dengan strategi elaborasi dan strategi konvensional. 4) Pada kelompok peserta didik bermotivasi belajar rendah, hasil belajar matematika peserta didik yang diajar dengan strategi elaborasi lebih tinggi secara signifikan dibandingkan dengan yang diajar menggunakan strategi konvensional. Dari hasil penelitian ditemukan bahwa secara signifikan terdapat interaksi pengaruh strategi belajar matematika dan tingkat motivasi belajar terhadap hasil belajar matematika. Secara keseluruhan ditemukan bahwa hasil belajar matematika peserta didik yang diajar dengan strategi belajar elaborasi lebih tinggi daripada strategi belajar konvensional.
\end{abstract}

Kata Kunci: Strategi Pembelajaran, Motivasi Belajar, Hasil Belajar Matematika.

\section{PENDAHULUAN}

Pendidikan Matematika di sekolah pada umumnya masih menekankan pada ranah kognitif, sehingga hasil belajar matematika masih tergolong rendah. Pernyataan senada diungkapkan oleh salah seorang pakar pendidikan matematika di Indonesia, Zulkardi, dalam salah satu artikelnya beliau memaparkan bahwa: masalah utama dalam pendidikan di Indonesia adalah rendahnya hasil belajar peserta didik di sekolah. Dalam konteks pendidikan matematika, sebagai contoh, hasil belajar dimaksud tidak hanya pada aspek 
kemampuan mengerti matematika sebagai pengetahuan atau kognitif tetapi juga aspek sikap atau attitude terhadap matematika. Indikasi masih rendahnya pendidikan matematika di Indonesia dapat dilihat dari perolehan nilai ujian akhir nasional untuk jenjang SD sampai SMA yang skornya relatif rendah.

Tujuan pendidikan termasuk di dalamnya tujuan pembelajaran, selain daripada daerah kognitif dan psikomotorik adalah daerah afektif. Gagne (dalam Suherman dan Kusumah, 1990:231) menyebutkan bahwa daerah afektif ini sebagai objek matematika yang sifatnya tidak langsung, yang dapat secara langsung dimiliki dalam diri peserta didik setelah kegiatan belajar mengajar berlangsung. Maulana (2002:21), menyatakan bahwa matematika di jenjang pendidikan dasar dan menengah diberikan dengan tujuan untuk:

1. Mempersiapkan peserta didik agar sanggup menghadapi perubahan keadaan dalam kehidupan dunia yang selalu berkembang melalui latihan bertindak atas dasar pemikiran secara logis, rasional kritis, cermat, jujur, efektif dan efisien.

2. Mempersiapkan peserta didik agar dapat menggunakan matematika dan pola pikir matematika dalam kehidupan sehari-hari.

Semua pihak menyadari bahwa matematika merupakan ilmu dasar yang harus dipelajari oleh setiap peserta didik. Di samping pelajaran bahasa, matematika merupakan pelajaran penting yang harus diajarkan pada setiap jenjang pendidikan, khususnya pendidikan dasar. Matematika merupakan pelajaran yang memberikan pondasi atau landasan orang untuk berlatih berpikir dan bernalar. Melalui kemampuan penalaran seseorang yang terus dilatih sehingga semakin berkembang, maka orang tersebut akan bertambah daya pikir dan pengetahuannya. Atas dasar inilah, matematika mutlak wajib diajarkan pada setiap peserta didik terlebih lagi untuk usia pendidikan dasar yaitu SD dan SMP.

Berdasar pada beberapa faktor penyebab rendahnya hasil belajar matematika tersebut, penulis lebih condong dan berkecenderungan bahwa faktor utama yang menyebabkan rendahnya mutu pembelajaran matematika disebabkan karena kurang tepatnya para guru dalam memilih strategi pembelajaran serta kurang mampunya guru dalam memberikan motivasi belajar pada peserta didik. Faktor strategi pembelajaran dan motivasi merupakan factor utama yang mempengaruhi hasil belajar. Selain itu pelajaran matematika di sekolah sering menjadi salah satu pelajaran yang ditakuti oleh sebagian besar peserta didik. Bahkan (Ruseffendi 1994:15) menyatakan bahwa "matematika bagi anak-anak pada umumnya merupakan mata pelajaran yang tidak di senangi, kalau bukan pelajaran yang di benci. Kegiatan-kegiatan yang dilakukan dalam rangka belajar diarahkan untuk mencapai tujuan pendidikan. Tujuan pendidikan harus sejalan dengan tuntutan pembangunan yang sedang dilaksanakan oleh pemerintah dan rakyat Indonesia.

Lebih jauh lagi Ngalim Purwanto (1992:14) mengatakan bahwa selain faktor lingkungan ada beberapa faktor lain lagi yang mempengaruhi prestasi belajar peserta didik diantaranya adalah strategi pembelajaran dan motivasi belajar peserta didik. Strategi pengelolaan pengajaran merupakan komponen variabel metode yang berurusan dengan bagaimana menata interaksi antar peserta didik dengan variabel-variabel metode pengajaran lainnya. Strategi pembelajaran elaborasi merupakan salah satu strategi pembelajaran yang saat ini sedang marak dipergunakan oleh kalangan akademis. Strategi pembelajaran elaborasi digunakan untuk mengorganisasi isi pembelajaran sehingga tahap pengajaran akan menjadi lebih mudah dan terarah. Pengorganisasian urutan isi pelajaran berdasarkan teori elaborasi dimulai dengan disajikannya gambaran tentang hal yang paling umum dan paling sederhana dari isi yang akan disampaikan. Dengan kata lain model pembelajaran elaborasi berbentuk piramida.

Motivasi merupakan salah satu determinan penting dalam belajar. Para ahli sukar mendefinisikannya, akan tetapi motivasi berhubungan dengan arah perilaku, kekuatan 
respon dan ketahanan prilaku (Martinis Yamin 2007:217). Motivasi belajar merupakan daya penggerak psikis dari dalam diri seseorang untuk dapat melakukan kegiatan belajar dan menambah keterampilan, pengalaman. Motivasi mendorong dan mengarah minat belajar untuk tercapai suatu tujuan. Peserta didik akan bersungguh-sungguh belajar karena termotivasi mencari prestasi. Dengan kata lain strategil pembelajaran mempengaruhi motivasi peserta didik dalam belajar karena model pembelajaran memberikan arah dan strategi pengorganisasian dalam proses belajar sehingga tercipta suasana belajar yang kondusif dan arah pelajaran yang jelas. Selain itu perlu diingat bahwa, pada setiap diri peserta didik mempunyai motivasi belajar yang tidak sama antara peserta didik yang satu dengan yang lainnya; ada peserta didik yang motinasi belajarnya tinggi dan pula yang rendah. Oleh karenanya setiap guru harus mampu memotivasi peserta didik dalam belajar agar motivasi yang ada pada diri peserta didik terespon secara optimal untuk meraih prestasi dalam belajar. Menurut Oemar Hamalik pada dasarnya prestasi belajar bergantung kepada dua unsur pokok yang saling mempengaruhi yakni motivasi peserta didik dalam belajar dan model pembelajaran yang digunakan. Atas dasar itu bahwa pelaksanaan pendidikan yang dilakukan dalam bentuk kegiatan pengajaran tidak terlepas dari motivasi peserta didik dan model pembelajaran.

Dari masalah yang ditemui di atas maka penulis akan melakukan studi koperhensif untuk menganalisis pengaruh model pembelajaran dan motivasi belajar peserta didik yang dituangkan dalam artikel yang berjudul "Pengaruh Strategi Pembelajaran Elaborasi Terhadap Hasil Belajar Matematika Ditinjau Dari Motivasi Belajar Peserta didik Eksperimen pada peserta didik kelas IX SMP Tugu Ibu Depok”.

\section{METODE}

Pada penelitian ini menggunakan metode eksperimen, yaitu dengan memberikan jenis perlakuan yang berbeda pada dua kelompok belajar peserta didik. Satu kelompok dijadikan sebagai kelompok eksperimen, yaitu diberikan perlakuan pembelajaran matematika dengan pendekatan elaborasi, sedangkan kelompok yang satu lagi sebagai kelompok control dengan perlakuan pembelajaran dengan pendekatan konvesional. Dari masing-masing kelompok kemudian dibagi kedalam peserta didik bermotivasi tinggi dan peserta didik bermotivasi rendah. Penelitian ini mengandung 2 validitas, yaitu validitas internal dan validitas eksternal. Validitas internal terkait dengan tingkat pengaruh perlakuan (treatment) atribut yang ada terhadap hasil belajar matematika peserta didik, yang didasarkan atas ketepatan prosedur dan data yang dikumpulkan serta penarikan kesimpulan. Sedangkan validitas eksternal terkait dengan dapat tidaknya hasil penelitian ini untuk digeneralisasikan pada subjek lain yang tidak memiliki kondisi dan karakteristik sama. Agar tujuan tersebut tercapai, maka dalam penelitian ini dilakukan pengontrolan pengaruh variable-variabel ekstra sebagai berikut :

1. Pengaruh variabel sejarah, dikontrol dengan pemberian materi pelajaran yang sama, dalam jangka waktu yang sama dan oleh guru yang sama.

2 Pengaruh variabel kematangan, dikontrol dengan cara proses treatment dalam variabel internal waktu yang tidak terlalu lama. Dengan demikian diharapkan mereka memiliki kesempatan perubahan mental maupun fisik yang sama pula.

3. Pengaruh variabel pretesting, dikontrol dengan jalan tidak memberikan pretest pada kedua kelompok sampel. Hal ini dilakukan agar pengalaman pretest tersebut tidak mempengaruhi penampilan subjek selama proses perlakuan.

4. Pengaruh variabel instrument, dikontrol dengan pemberian test yang sama pada kelompok eksperimen dan control 
5. Pengaruh variabel mortalitas, dikontrol dengan pemberian perlakuan yang sama pada peserta didik lain yang tidak menjadi anggota sampel, sehingga jika terjadi mortalitas dapat secepatnya diganti dengan peserta didik lain yang setara

6. Pengaruh interaksi antar subjek, dikontrol dengan tidak memberitahukan, bahwa sedang dilakukan proses penelitian dan memberikan kegiatan proses pembelajaran yang berbeda.

Sebagai usaha mengontrol validitas eksternal dilakukan sebagai berikut :

1) Interaksi pembelajaran dengan pendekatan matematikan elaborasi dan konvesional serta motivasi belajar, dikontrol dengan pengambilan kelas eksperimen dan control seimbang. Hal ini dilakukan agar kondisi awal pada kedua kelas diasumsikan sama. Kemudian kedua kelas percobaan diberi perlakuan yang berbeda.

2) Pengaturan penelitian reaktif, dikontrol dengan :

a. Suasana perlakuan tidak artificial sehingga tidak merasa sedang diteliti

b. Subjek tidak diberikan informasi bahwa sedang diteliti

c. Perlakuan untuk semua peserta didik dalam satu kelas belajar sama baik yang dijadikan sample maupun yang tidak dijadikan sample

d. Guru diusahakan hanya satu orang untuk kedua kelas eksperimen

Penelitian ini menggunakan metode eksperimen dengan disain treatmen by level factorial 2 x 2 sebagai berikut :

Tabel 1

\begin{tabular}{|c|c|c|}
\hline Motivasi Pendekatan Belajar & K - 1 & K - 2 \\
\hline B - 1 & Y 11 & Y 12 \\
\hline B -2 & Y 21 & Y 22 \\
\hline
\end{tabular}

Keterangan :

$\mathrm{K}-1=$ Strategi Pembelajaran Matematika Elaborasi

$\mathrm{K}-2$ = Strategi Pembelajaran Matematika Konvensional

$\mathrm{B}-1=$ Motivasi belajar tinggi

$\mathrm{B}-2$ = Motivasi belajar rendah

$\mathrm{Y}_{11}=$ Hasil belajar matematika peserta didik dengan pembelajaran matematika Elaborasi dan motivasi belajar tinggi

$\mathrm{Y}_{12}=$ Hasil belajar matematika peserta didik dengan pembelajaran matematika konvensional/mekanistik dan motivasi belajar tinggi

$\mathrm{Y}_{21}=$ Hasil belajar matematika peserta didik dengan pembelajaran matematika Elaborasi dan motivasi belajar rendah

$\mathrm{Y}_{22}=$ Hasil belajar matematika peserta didik dengan pembelajaran matematika konvesional/mekanistik dan motivasi belajar rendah 


\section{HASIL DAN PEMBAHASAN Analisis Deskriptif Data}

Tabel 2. Rangkuman Data Deskriptif

\begin{tabular}{|l|l|l|l|l|l|l|l|l|}
\hline \multirow{2}{*}{ Kelompok } & \multirow{2}{*}{$\mathbf{N}$} & \multicolumn{6}{l}{ Skor Hasil Belajar } \\
\cline { 3 - 9 } & & Max & Min & Mean & Modus & Median & Varians & SD \\
\hline E & 20 & 20 & 8 & 16,3 & 17 & 17 & 8,556 & 2,923 \\
\hline K & 20 & 19 & 5 & 14,6 & 15 & 14 & 10,400 & 3,225 \\
\hline ET & 10 & 20 & 9 & 16,3 & 18 & 17,5 & 10,409 & 3,226 \\
\hline ER & 10 & 20 & 13 & 17,2 & 17 & 17 & 5,157 & 2,271 \\
\hline KT & 10 & 20 & 9 & 16.4 & 17 & 16,5 & 9,6400 & 3,1048 \\
\hline KR & 10 & 16 & 5 & 9,1 & 8,9 & 8,5 & 12,090 & 3,477 \\
\hline
\end{tabular}

Dari tabel rangkuman statistik deskriptif di atas menunjukkan, bahwa nilai rerata (mean) yang paling besar adalah nilai ER (kelompok peserta didik yang tingkat motivasi rendah yang belajar dengan menggunakan strategi pembelajaran elaborasi), apabila peserta didik diajar melalui sterategi elaborasi dan peserta didik memiliki tingkat motivasi rendah, akan menghasilkan hasil belajar matematika tertinggi atau dengan kata lain bahwa strategi belajar elaborasi efektif untuk peserta didik yang bemotivasi rendah. Sedangkan rerata terendah diperoleh kelompok KR (kelompok peserta didik dengan tingkat motivasi rendah yang belajar dengan strategi pembelajaran konvensional), ini menunjukkan bahwa peserta didik yang memiliki tingkat motivasi rendah dan diajar dengan strategi belajar konvensional akan menghasilkan hasil belajar matematika yang rendah atau dengan kata lain bahwa strategi pembelajaran konvensional tidak efektif digunakan pada peserta didik yang bermotivasi belajar rendah.

\section{Pengujian Prasyarat Analisis Data}

\section{Uji Normalitas}

Pengujian normalitas terhadap data penelitian menggunakan uji Liliefors yang dilakukan secara komputerisasi melalui prgram Micosoft Excel 2007, yang secara lengkap dapat dilihat pada lampiran 14 halaman 179. Uji normalitas dilakukan untuk menguji hipotesis sebagai berikiut :

H0 : Data berasal dari populasi berdistribusi normal

H1 : Data tidak berasal dari populasi berdistribusi normal

Kriteria pengujian hipotesis, yaitu :

Terima H0 (tolak H1) jika Lo $<\mathrm{L}_{\text {tabel }}$ atau Tolak H0 (terima H1) jika Lo $>\mathrm{L}_{\text {tabel }}$

Rangkuman hasil analisis uji normalitas menggunakan Lilifors dengan taraf signifikansi $\alpha$ $=0,05(5 \%)$ untuk masing-masing kelompok data hasil belajar matematika peserta didik (ET,ER,KT, dan KR) disajikan sebagai berikut.

Tabel 3. Rangkuman Hasil Uji Normalitas Data dengan $\alpha=0,05$

\begin{tabular}{|l|l|l|l|l|}
\hline No & Kelompok Data & Harga Lo & Harga $\mathrm{L}_{t}$ & Kesimpulan \\
\hline 1. & ET & 0,1379 & 0,2580 & Berdistribusi normal \\
\hline 2. & ER & 0,1319 & 0,2580 & Berdistribusi normal \\
\hline 3. & KT & 0,1093 & 0,2580 & Berdistribusi normal \\
\hline 4. & KR & 0,1985 & 0,2580 & Berdistribusi normal \\
\hline 5. & EKS & 0,1335 & 0,1900 & Berdistribusi normal \\
\hline 6. & KTR & 0,1635 & 0,1900 & Berdistribusi normal \\
\hline
\end{tabular}


Hasil perhitungan menunjukkan bahwa untuk semua kelompok data ET,ER, KT, KR. EKS dan KTR, diperoleh nilai Lo lebih kecil dari $\mathrm{L}_{\text {tabel }}$. Dengan demikian dapat disimpulkan seluruh kelompok data berasal dari populasi berdistribusi normal.

\section{Pengujian Hipotesis Penelitian}

Analisis data untuk menguji hipotesis pada penelitian ini melalui tehnik analisis of varians (ANOVA) dua jalur yang dilakukan secara komputerisasi melalui program Microsoft Excel 2007 dan rangkumamnya terlihat dalam tabel berikut:

Tabel 4. Statistik Deskriptif untuk ANOVA Dua Arah

\begin{tabular}{|c|c|c|c|c|}
\hline \multicolumn{4}{|c|}{ Strategi Pembelajaran Matematika } & \multirow{2}{*}{$\sum \mathrm{B}$} \\
\hline \multirow{3}{*}{ Motivasi } & & Elaborasi & onal & \\
\hline & Tinggi & $\begin{array}{l}\mathrm{n}=10 \\
\tilde{Y}=16,3 \\
\sum \mathrm{Y}=163 \\
\sum \mathrm{Y}^{2}=2741\end{array}$ & $\begin{array}{l}\mathrm{n}=10 \\
\tilde{\mathrm{Y}}=16,4 \\
\sum \mathrm{Y}=164 \\
\sum \mathrm{Y}^{2}=2643\end{array}$ & $\begin{array}{l}\mathrm{n}=10 \\
\tilde{\mathrm{Y}}=16,3 \\
\sum \mathrm{Y}=324 \\
\sum \mathrm{Y}^{2}=5384\end{array}$ \\
\hline & Rendah & $\begin{array}{l}\mathrm{n}=10 \\
\tilde{\mathrm{Y}}=17,2 \\
\sum \mathrm{Y}=172 \\
\sum \mathrm{Y}^{2}=2950\end{array}$ & $\begin{array}{l}\mathrm{n}=10 \\
\tilde{\mathrm{Y}}=9,1 \\
\sum \mathrm{Y}=91 \\
\sum \mathrm{Y}^{2}=949\end{array}$ & $\begin{array}{l}\mathrm{n}=10 \\
\tilde{\mathrm{Y}}=13,5 \\
\sum \mathrm{Y}=263 \\
\sum \mathrm{Y}^{2}=3899\end{array}$ \\
\hline \multicolumn{2}{|l|}{$\sum \mathrm{K}$} & $\begin{array}{l}\mathrm{n}=20 \\
\tilde{\mathrm{Y}}=16,7 \\
\sum \mathrm{Y}=335 \\
\sum \mathrm{Y}^{2}=5691\end{array}$ & $\begin{array}{l}\mathrm{n}=20 \\
\tilde{\mathrm{Y}}=12,6 \\
\sum \mathrm{Y}=252 \\
\sum \mathrm{Y}^{2}=3592\end{array}$ & $\begin{array}{l}\mathrm{n}=40 \\
\tilde{\mathrm{Y}}=14,6 \\
\sum \mathrm{Y}=587 \\
\sum \mathrm{Y}^{2}=9283\end{array}$ \\
\hline
\end{tabular}

Dari data deskriptif tersebut selanjutnya diolah untuk mendapatkan tabel rangkuman untuk pengujian hipotesis dengan menggunakan analysis of varians (ANOVA) dua jalur sebagai berikut :

Tabel 5. Rangkuman Hasil Analisis Sumber Varians Untuk ANOVA Dua Arah

\begin{tabular}{|c|c|c|c|c|c|c|}
\hline \multirow[t]{2}{*}{ Sumber Varians } & \multirow[t]{2}{*}{$\mathrm{db}$} & \multirow[t]{2}{*}{ JK } & \multirow[t]{2}{*}{ RJK } & \multirow[t]{2}{*}{$\mathrm{Fh}$} & \multicolumn{2}{|l|}{$\mathrm{Ft}$} \\
\hline & & & & & $\alpha=0,05$ & $\alpha=0,01$ \\
\hline Antar Kolom (Ak) & 1 & 93,025 & 93,025 & 12,674 & 4.11 & 7.39 \\
\hline Antar Baris (Ab) & 1 & 172,225 & 172,225 & 23,464 & 4.11 & 7.39 \\
\hline Interaksi (I) & 1 & 381,275 & 381,275 & 51,945 & 4.11 & 7.39 \\
\hline Antar Kelompok (A) & 3 & 430,5 & 143,5 & 1,627 & - & - \\
\hline Dalam Kelompok (D) & 36 & 264,3 & 7,34 & - & - & - \\
\hline Total di Reduksi (TR) & 39 & 694,8 & 17,82 & - & - & - \\
\hline
\end{tabular}




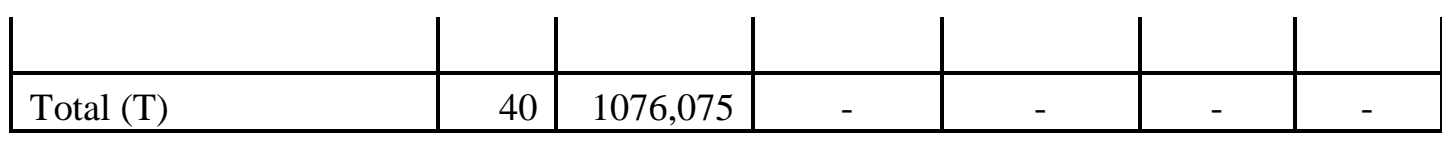

\section{Pengujian Hipotesis Pertama}

Hipotesis yang akan diuji dalam hipotesis pertama yaitu dinyatakan dalam hipotesis statistik sebagaiberikut :

$H o: \mu_{01}=\mu_{02}$ (tidak ada perbedaan hasil belajar matematika peserta didik yang belajar dengan strategi pembelajaran elaborasi matematika dan strategi konvensional)

H1 : $\mu_{01}=\mu_{02}$ (hasil belajar matematika peserta didik yang belajar dengan strategi pembelajaran elaborasi matematika lebih tinggi daripada strategi konvensional)

Dari tabel 4 (rangkuman hasil perhitungan tehnik ANOVA dua jalur) diatas, diperoleh bahwa hasil analisis data pada kelompok strategi belajar matematika antara strategi elaborasi dengan strategi konvensional (antar faktor) diperoleh harga $\mathrm{F}_{\text {hitung. }}=12,674$ lebih besar dari harga $\mathrm{F}_{\text {tabel }}=4,11$ pada tingkat signifikansi 5\%, Ini berarti dalam pengujian hipotesis pertama menolak $\mathrm{H} 0$ dan menerima $\mathrm{H} 1$, dengan demikian hipotesis pertama teruji kebenarannya secara signifikan dan dapat diterima. Dengan demikian terdapat perbedaan pengaruh yang signifikan strategi belajar matematika elaborasi dan konvensional terhadap hasil belajar peserta didik pada mata pelajaran matematika. Ratarata hasil belajar matematika yang belajar dengan strategi pembelajaran elaborasi lebih tinggi secara signifikan daripada yang belajar dengan strategi pembelajaran konvensional. Hal tersebut, ditunjukkan dari hasil analisis deskriptif yang disajikan dalam tabel 19 (tabel rangkuman data deskriptif) diatas, bahwa hasil belajar matematika peserta didik yang belajar dengan strategi belajar elaborasi diperoleh hasil : mean 16,3 ; modus 17 ; simpangan baku 2,9 ; skor tertinggi 20 dan skor terendah 8 dari skor total 20. Sedangkan pada kelompok peserta didik yang diajar dengan strategi konvensional diperoleh hasil belajar matematika : mean 14 ; modus 16 ; simpangan baku 3,2 ; skor tertinggi 20 serta skor terendah 5 dari skor total 20.

Dari data ini terlihat, bahwa selain teruji hasil belajar matematika peserta didik yang belajar dengan strategi elaborasi lebih tinggi secara signifikan dari pada yang belajar dengan strategi konvensional juga tingkat variasi perolehan skor antar peserta didik pada kelompok yang belajar dengan strategi elaborasi lebih uniform (homogen) dari pada yang belajar dengan pembelajaran konvensional. Hal ini karena, simpangan baku skor hasil belajar matematika peserta didik yang belajar dengan strategi elaborasi sebesar 2,9 sedangkan pada peserta didik yang diajar dengan strategi konvensional 3,2. Simpangan baku pada kelompok peserta didik yang belajar dengan strategi elaborasi lebih kecil dari pada yang belajar dengan strategi konvensional.

Fenomena ini menunjukkan bahwa hasil belajar mata pelajaran matematika akan meningkat bila siswa diajar dengan strategi belajar elaborasi. Artinya semakin baik penerapan strategi belajar elaborasi, maka akan menghasilkan hasil belajar matematika yang semakin baik pula. Hal ini terjadi karena dampak dari hasil pembelajaran elaborasi yaitu meningkatkan hasil belajar siswa.

\section{Pengujian Hipotesis Kedua}

Hipotesis yang akan diuji dalam hipotesis kedua yaitu dinyatakan dalam hipotesis statestik sebagai berikut : 
$H_{0}$ : Int. $A x B=0$ (Tidak terdapat interaksi pengaruh antara strategi pembelajaran matematika dan motivasi belajar terhadap hasil belajar matematika peserta didik)

$H_{1}$ : Int. $A x B=0$ (Terdapat interaksi pengaruh antara strategi pembelajaran matematika dan motivasi belajar terhadap hasil belajar matematika peserta didik)

Dari tabel 4 (tabel rangkuman hasil perhitungan teknik ANOVA dua jalur) di atas, diperoleh bahwa hasil analisis data pada interaksi strategi belajar metematika dan tingkat motivasi belajar yaitu yang menganalisis varians pada 4 kelompok data hasil belajar matematika (kelompok elaborasi motivasi tinggi, elaborasi motivasi rendah, konvensional - motivasi tinggi dan konvensional - motivasi rendah) diperoleh harga $\mathrm{F}_{\text {hitung }}=51,945$ lebih besar dari harga $\mathrm{F}_{\text {tabel }}$ sebesar 4,11 pada tingkat $\alpha=5 \%$.

Hasil ini menunjukkan penolakan H0 dan menerima H1, dengan demikian hipotesis kedua teruji kebenarannya dan dapat diterima. Dengan demikiandapat disimpulkan terdapat interaksi pengaruh yang signifikan antara strategi belajar matematika dan tingkat motifvasi belajar terhadap hasil belajar matematika peserta didik.

Dari hasil analisis deskriptif di atas, ditujukan bahwa rata-rata (mean) hasil belajar matematika kelompok peserta didik yang belajar dengan strategi elaborasi dan bermotivasi belajar rendah, yaitu sebesar 17,2. Sedangkan pada kelompok peserta didik yang belajar dengan strategi konvensional dan bermotifasi belajar tinggi diperoleh ratarata $($ mean $)=16,4$ lebih tinggi dari kelompok yang diajar dengan strategi konvensional tetapi bermotivasi belajar rendah, yaitu sebesar 9,1. Skor data mean hasil belajar matematika dari keempat kelompok tersebut menunjukkan adanya interaksi pengaruh antara strategi pembelajaran elaborasi matematika dan motivasi belajar terhadap hasil belajar matematika peserta didik, sehingga $\mathrm{H} 1$ dapat diterima.

Hasil dari pembahasan di atas bahwa pada siswa yang bermotivasi belajar tinggi, pembelajaran matematika sama efektifnya antara strategi elaborasi dengan konvensional ; sedangkan untuk yang bermotivasi belajar rendah pembelajaran matematika akan lebih efektif bila menggunakan strategi belajar elaborasi.

\section{Pengujian Hipotesis Ketiga}

Hipotesis yang akan diuji dalam hipotesis ketiga yaitu dinyatakan dalam hipotesis stateistik sebagai berikut :

Ho $: \mu_{11}=\mu_{12}$ (tidak ada perbedaan yang signifikan hasil belajar matematika peserta didik yang belajar dengan strategi elaborasi dan strategi konvensional, pada peserta didik bermotivasi belajar tinggi)

$H_{1}: \mu_{11}>\mu_{12}$ (hasil belajar matematika peserta didik yang belajar dengan strategi elaborasi lebih tinggi daripada strategi konvensional, pada peserta didik yang bermotivasi belajar tinggi).

Karena jumlah subyek sampel pada masing-masing kelompok yang akan dianalisis sama, maka pengujian hipotesis ketiga ini menggunakan uji tukey. Kriteria pengujian, yaitu terima Ho (tolak H1) jika Qhitung lebih kecil dari $Q_{\text {tabel }}$ dan tolak Ho (terima H1) jika $\mathrm{Q}_{\text {hitung }}$ lebih besar dari $\mathrm{Q}_{\text {tabel. }}$.

Dari hasil perhitungan, untuk $\alpha=0,05$ diperoleh $\mathrm{Q}_{\text {hitung }}=0,743$ lebih kecil daripada $\mathrm{Q}_{\text {tabel }}=1,743$. Hasil ini menunjukkan kondisi penerimaan Ho dan penolakkan H1 pada pengujian hipotesis ini, dengan demikian hipotesis ketiga tidak teruji kebenarannya. Dengan demikian disimpulkan, bahwa pada kelompok peserta didik yang bermotivasi belajar tinggi, tidak ada perbedaan yang signifikan hasil belajar matematika antara peserta didik yang diajar dengan strategi belajar elaborasi dengan strategi konvensional. 
Hal tersebut, ditunjukkan dari hasil analisis deskriptif yang disajikan dalam tabel 19 diatas, bahwa pada kelompok peserta didik yang memiliki motivasi belajar tinggi, untuk peserta didik yang belajar dengan strategi elaborasi diperoleh skor hasil belajar matematika : mean 16,3, simpangan baku 3,2, skor tertinggi 20 dan skor terendah 9 dari total skor 20. Sedangkan pada kelompok peserta didik yang bermotivasi belajar tinggi ini, bila belajar dengan strategi belajar konvensional diperoleh hasil belajar matematika : mean 16,4, simpangan baku 3,1, skor tertinggi 20 serta skor terendah 9 dari total skor 20. Dari data ini terlihat bahwa selain tidak teruji kebenarannya bahwa hasil belajar matematika peserta didik yang belajar dengan strategi elaborasi lebih tinggi daripada yang belajar dengan strategi konvensional; juga tingkat variasi perolehan skor antar peserta didik pada kelompok yang belajar dengan strategi elaborasi lebih bervariatif daripada yang belajar dengan strategi konvensional. Hal tersebut karena, simpangan baku skor hasil belajar matematika peserta didik yang diajar dengan strategi elaborasi sebesar 3,2 dan rentangnya 11, sedangkan pada peserta didik yang belajar dengan strategi konvensional diperoleh simpangan baku 3,1 dan rentang nilai sama yaitu 11. Simpangan baku yang belajar dengan strategi elaborasi lebih besar daraipada yang belajar dengan strategi konvensional, sehingga pengujian hipotesis ketiga $\mathrm{H} 1$ diterima.

Dengan demikian pembahasan di atas, untuk mereka yang memiliki motivasi belajar tinggi, sama efektifnya dalam pembelajaran matematika antara diajar dengan strategi elaborasi maupun strategi konvensional. Hal ini terjadi karena salah satu manfaat pemebelajaran elaborasi yaitu meningkatkan motivasi belajar siswa.

\section{Pengujian Hipotesis Keempat}

Hipotesis yang akan diuji dalam hipotesis keempat yaitu dinyatakan dalam hipotesis statistik sebagai berikut :

$H_{0}: \mu_{21}=\mu_{22}$ (Tidak ada perbedaan hasil belajar matematika peserta didik yang belajar dengan strategi elaborasi dan strategi konvensional, pada kelompok peserta didik bermotifasi belajar rendah).

$H_{1}: \mu_{21}>\mu_{22}$ (Hasil belajar matematika peserta didik yang diajar dengan strategi elaborasi lebih tinggi dari pada dengan strategi konvensional, pada kelompok peserta didik bermotivasi belajar rendah)

Seperti pada pengujian hipotesis ketiga, dalam pengujian hipotesis keempat ini karena jumlah subjek sempel pada masing - masing kelompok yang akan dianalisis sama, maka pengujian hipotesis keempat ini menggunakan uji tukey. Kriteria pengujian, yaitu terima H0 (tolak H1) jika $\mathrm{Q}_{\text {hitung }}$ lebih kecil dari $\mathrm{Q}_{\text {tabel}}$, dan tolak H0 (terima H1) jika $\mathrm{Q}_{\text {hitung }}$ lebih besar dari $\mathrm{Q}_{\text {tabel. }}$.

Dari hasil perhitungan, untuk $\alpha=0,05$ diperoleh $\mathrm{Q}_{\text {hitung }}=5,778$ lebih besar dari pada $\mathrm{Q}_{\text {tabel }}=1,734$. Hal ini menunjukkan kondisi penolakan $\mathrm{H} 0$ dan penerimaan $\mathrm{H} 1$, dengan demikian hipotesis keempat teruji kebenarannya secara signifikan dan dapat diterima. Dengan demikian disimpulkan, bahwa pada kelompok peserta didik yang bermotivasi belajar rendah, hasil belajar matematika peserta didik yang belajar dengan strategi pembelajaran elaborasi lebih tinggi dari pada yang belajar dengan strategi konvensional.

Hal tersebut, ditujukan pula dari hasil analisis deskriptis di atas, bahwa pada kelompok peserta didik yang memiliki motivasi belajar rendah, untuk peserta didik yang belajar dengan strategi pembelajaran elaborasi diperoleh skor hasil belajar matematika : mean 17,2 ; modus 17 ; simpangan baku 2,3 ; skor tertinggi 20 dan skor terendah 13 dari skor total 20. Sedangkan pada kelompok peserta didik yang bermotivasi belajar rendah ini, bila diajar dengan strategi konvensional diperoleh hasil belajar matematika : mean 9,1 ; modus 9 ; simpangan baku 3,58 ; skor tertinggi 16 serta skor terendah 5 dari skor total 
20. Dari data ini terlihat, teruji kebenarannya bahwa hasil belajar matematika peserta didik yang diajar dengan strategi elaborasi lebih tinggi secara signifikan dari pada yang belajar dengan strategi konvensional ; juga tingkat variasi perolehan skor antar peserta didik pada kelompok yang belajar dengan strategi elaborasi lebih uniform (homogen) dari pada yang diajar dengan strategi konvensional. Hal tersebut, karena simpangan baku skor hasil belajar matematika peserta didik yang diajar dengan strategi elaborasi sebesar 2,9 dan rentanggnya 14 ; sedangkan pada peserta didik yang belajar dengan strategi konvensional diperoleh simpangan baku pada kelompok peserta didik yang belajar dengan strategi elaborasi lebih kecil pada yang belajar dengan strategi konvensional. Hal ini terjadi karena pada peserta didik yang bermotivasi belajar rendah jika belajar dengan menggunakan pembelajaran elaborasi, maka akan meningkatkan motivasi belajar rendah menjadi motivasi belajar tinggi.

Pembahasan di atas artinya untuk mereka yang memiliki motivasi belajar rendah, pembelajaran matematika dengan strategi elaborasi akan berperan sebagai motivasi eksternal yang dapat mendorong siswa untuk lebih tertarik belajar matematika. Sehingga proses pembelajaran matematika akan jauh lebih efektif menggunakan strategi elaborasi dari pada strategi konvensional. Karena dengan pembelajaran elaborasi siswa menjadi termotivasi untuk belajar dan akan berdampak pada hasil belajar yang lebih baik.

\section{PENUTUP}

Berdasarkan dari hasil pengujian hipotesis penelitian dan analisis pengolahan data, maka hasil penelitian dengan judul : Perbedaan Pengaruh Strategi Belajar Elaborasi Dan Konvensional pada Peserta didik yang Bermotivasi Belajar Tinggi dan Rendah (eksperimen pada peserta didik SMP Tugu Ibu Depok tahun pelajaran 2014/2015). Dengan jumlah sampel 40 peserta didik dan hasil kesimpulannya sebagai berikut:

1. Hasil belajar matematika peserta didik yang belajar dengan strategi belajar elaborasi lebih tinggi dari peserta didik yang diajar dengan strategi konvensional, atau dengan kata lain terdapat perbedaan pengaruh yang signifikan antara strategi belajar elaborasi dengan konvensional terhadap hasil belajar matematika peserta didik. Hal ini berdasarkan hasil analisis data pada kelompok strategi pembelajaran matematika diperoleh harga $\mathrm{F}_{\text {hitung }}$ sebesar 12,674 lebih besar dari $\mathrm{F}_{\text {tabel }}$ sebesar 4,11 pada tingkat signifikan $5 \%$ dan rerata skor hasil pembelajaran elaborasi $=16,7$ lebih besar dari rerata skor hasil belajar metematika peserta didik yang diajar dengan strategi pembelajaran konvensional = 12,6.

2. Terdapat pengaruh interaksi yang signifikan antara strategi pembelajaran matematika dan tingkat motivasi belajar terhadap hasil belajar matematika peserta didik. Hal ini berdasarkan pada hasil analisis data interaksi strategi pembelajaran matematika dan tingkat motivasi belajar, diperoleh harga $\mathrm{F}_{\text {hitung }}=51,945$ lebih besar dari harga $\mathrm{F}_{\text {tabel }}$ 4,11 pada tingkat signifikasi 5\% dan rerata skor hasil belajar matematika pada peserta didik dengan tingkat motivasi belajar tinggi yang diajar dengan strategi elaborasi 16,3 hampir sama dengan rerata skor hasil belajar matematika bila diajar dengan strategi konvensional 16,6 sedangkan rerata skor hasil belajar matematika pada peserta didik dengan tingkat motivasi belajar rendah yang diajar dengan strategi pembelajaran elaborasi 17,2 jauh lebih besar dari rerata skor bila diajar dengan strategi pembelajaran konvensional $=9,1$.

3. Pada kelompok peserta didik bermotivasi belajar tinggi, tidak terdapat perbedaan hasil belajar matematika yang signifikan antara yang diajar dengan strategi elaborasi dan strategi konvensional. Hal ini didasarkan pada hasil analisis data dan pengujian hipotesis dengan uji tukey pada kelompok ini, diperoleh nilai Qhitung $=0,743<$ Qtabel $=4,11$ pada taraf signifikansi $\alpha=0,05$ dan perolehan rerata skor hasil belajar 
matematika yang menggunakan strategi elaborasi $=16,3$ hampir sama dengan pendekatan konvensional $=18,7$.

4. Pada kelompok peserta didik bermotivasi belajar rendah, hasil belajar matematika peserta didik yang diajar dengan strategi elaborasi lebih tinggi secara signifikan dibandingkan dengan yang diajar menggunakan strategi konvensional. Hal ini didasarkan pada hasil analisis data dan pengujian hipotesis dengan uji tukey pada kelompok ini, diperoleh nilai Qhitung $=5,778>$ Qtabel 4,11 pada taraf signifikansi $\alpha$ $=0,05$ dan perolehan rerata skor hasil belajar matematika yang menggunakan strategi elaborasi $=17,2$ jauh lebih besar dari pada menggunakan strategi konvensional =9,1 .

\section{DAFTAR PUSTAKA}

Andi Hakim Nasution. 1982. Landasan Matematika. Bhrata Karya Aksara. Jakarta. Arikunto, Suharsimi.1992. Dasar-dasar Evaluasi Pendidikan. Bumi Aksara. Jakarta.

Arikunto, Suharsimi. 2002. Prosedur PenelitianSuatu Pendekatan Praktek (Edisi Revisi V). Jakarta: Rineka Cipta

Badudu. J.S. dan Sutan Muhammad Zain. 1996. Kamus Umum Bahasa Indonesia. Jakarta: Pustaka Sinar Harapan

Buchori Kifli dan Mustofa Usman. 1985. Prinsip-prinsip Matematika. Sinar Baru. Bandung.

Depdiknas. 2006. Kurikulum Tingkat Satuan Pendidikan. Jakarta: Depdiknas

Daiman.1994. Matematika 1. Ganeca Exact. Bandung.

Departemen Pendidikan dan Kebudayaan. 1994. Sistem Pendidikan Nasional. Jakarta.

Departemen Pendidikan dan Kebudayaan. 1994. Kurikulum Pendidikan Dasar. GBPP Mata Pelajaran Matematika. Jakarta.

Hamalik, Oemar. 2004. Proses Belajar Mengajar. Jakarta: PT. Bumi Aksara Hudoyo, Herman. 1990. Strategi Mengajar Matematika. IKIP Malang. Malang. Hudoyo, Herman. 1988. Mengajar Belajar Matematika. Jakarta: Depdikbud Jujun Suriasumantri. 1993. Filsafat Ilmu Sebuah Pengantar Populer. Sinar Harapan. Jakarta.

Lubis, Zulkifli. 1998. Teori Belajar. Jakarta: STKIP Wijya Bakti

Morgan. Cliffor T. and Richard A. King and Nancy M. Robinson. 1979. Introduction to Phschology. Tokyo: McGraw Hill \& Kogakusha Limited

Mohammad Nazir. 1988. Metode Penelitian. Ghalia Indonesia. Jakarta.

Nasution, Andi Hakim. 1980. Landasan Matematika. Jakarta: Bhratara Karya Aksar . 1992. Didaktik Azas-Azas Mengajar. Bandung: Jemmars

Ng Kim Choy. 2000. Pendekatan. Strategi. Kaedah dan Tehnik?. Situs http://www.teachersrock.net/pdkt.htm

Purwanto M. Ngalim. 1988. Psikologi Pendidikan. Remaja Rosdakarya. Bandung. Prayitno, Elida. 1989. Motivasi Dalam Belajar. Jakarta : Depdikbud

Rasyad, Aminudin. 2003. Teori Belajar dan Pembelajaran. Jakarta: UHAMKA Press \& Yayasan PEP-Ex 8

Ridwan. 2005. Belajar mudah Penelitian untuk Guru- karyawan dan Peneliti Pemula. Bandung: Alfabeta

Rohani, Ahmad dan Abu Ahmadi. 1991. Pengelolaan Pengajaran. Jakarta: Rineka Cipta Rohani, Ahmad dan Abu Ahmadi. 1990. Prinsip-prinsip dan Teknik Evaluasi Pendidikan. PT. Remaja Rosdakarya. Bandung.

Russefendi. 1980. Pengantar Matematika. Tarsito. Bandung.

Rusyan Tabrani. 1993. Proses Belajar Mengajar Yang Efektif. PT. Bina Budhaya. Jakarta. 
Ridho Mochammad dkk. 2006. Pendalaman Materi Sukses Ujian Nasional. Akasia. Jakarta

Suherman, Eman. dkk. 2003. Strategi Pembelajaran Matematika Kontenporer. Bandung: BEPI

Slameto. 1995. Belajar dan Faktor-faktor yang Mempengaruhinya. PT. Raneka Cipta. Jakarta.

Sudjana Nana. 1990. Penilaian Hasil Proses Belajar Mengajar. PT. Remaja Rosdakarya. Bandung.

Sudjana Nana. 1992. Teknik Analisis Regresi dan Korelasi. Tarsito. Bandung.

Sudjana Nana. 1991. Teori-teori Belajar untuk Pengajaran. Lembaga Penerbit. FEUI. Jakarta.

Sugiyono. 2004. Metode Penelitian Administrasi. Bandung: Afabeta

Suriasumantri. Jujun S. 1993. Filsafat Ilmu (Sebuah Pengantar Populer). Jakarta: Gramedia

Suparman. Atwi 2005. Disain Instrumentional. Proyek Pengembangan Pusat Fasilitas. Jakarta.

Soemanto Wasty.1988. Psikologi Pendidikan. Remaja Rosdakarya. Bandung.

Uno. Hamzah. 1991. Model Pembelajaran. Bumi Aksara. Jakarta.

W. S. Winkel. 1987. Psikologi Pengajaran. PT. Gramedia. Jakarta.

Yamin. Martinus. 2007. Kiat Membelajarkan Peserta didik. Gaung Persada Press. Jakarta.

Zulkardi. 2013. How to Design Mathematics Lessons based on the Reastic Approach. Situs: www.geocities.com/ratuilmu.co.id 